\title{
Vitamin D Supplements Improve Efficacy of Minocycline, N-Acetylcysteine and Aspirin Triple Therapy to COVID-19 Infection
}

\author{
Mosab Nouraldein Mohammed Hamad \\ Research Unit, Banoon Fertility Center, Sudan
}

DOI: $\underline{10.36348 / \text { sjbr.2020.v05i04.005 }}$

| Received: 07.04.2020 | Accepted: 16.04.2020 | Published: 24.04 .2020

*Corresponding author: Mosab Nouraldein Mohammed Hamad

Abstract

Vitamin D is a fat soluble hormone, with a well explained function in bone fitness and calcium/phosphate metabolism. Current proofs have linked vitamin D to other physiological functions and pathological states. Addition of vitamin D supplements to the theorized (Minocycline, N-acetylcysteine and Aspirin) triple combined therapy to COVID-19, may improve the therapeutic efficacy of the joint therapy. Invivo and invitro laboratory experiments will confirm this theory about COVID-19 crisis.

Keywords: Vitamin D, Minocycline, N-acetylcysteine, Aspirin, COVID-19.

Copyright @ 2020: This is an open-access article distributed under the terms of the Creative Commons Attribution license which permits unrestricted use, distribution, and reproduction in any medium for non-commercial use (NonCommercial, or CC-BY-NC) provided the original author and source are credited.

\section{INTRODUCTION}

Vitamin D is a steroid hormone that plays a chief function in regulation of natural immunity. The majority of tissues express the vitamin D receptor, allowing a response to the hormone. Humans get vitamin D precursors from exposure to sunlight and to a much smaller degree from diet. Respiratory epithelial cells constitutively stimulate vitamin D and are capable of creating a microenvironment that has high levels of active form of the vitamin. Activation has downstream influences that contain up-regulation of the cathelicidin antimicrobial peptide gene and the TLR, coreceptor, CD14. Viral infection leads to raised activation of vitamin $\mathrm{D}$ and additional increases in cathelicidin mRNA. Cathelicidin is recognized to be a significant constituent of natural immunity in the lungs and thus restricted vitamin $\mathrm{D}$ activation might be a significant part of host defense [1].

It is progressively more documented that restricted production of $1,25 \mathrm{D}$ rather than systemic production is accountable for several of the immune influences of vitamin D. Extra-renal expression of $1 \alpha-$ hydroxylase has been found in various cells of the immune system counting alveolar macrophages, dendritic cells, and lymphocytes in addition to in airway epithelia. Nearby synthesized 1,25D acts in an autocrine or paracrine manner to adjust cell proliferation, cell differentiation and immune function. Restricted creation of active vitamin $\mathrm{D}$ in the lung probable regulates pulmonary immune responses [2].
Vitamin D may progress endings by dropping both local and systemic inflammatory responses as a consequence of modulating cytokine responses and plummeting Toll-like receptor (TLR) activation. Proof exists that vitamin $\mathrm{D}$ may have a defensive function in influenza, and other viral illnesses, such as the jeopardy of developing acquired immunodeficiency syndrome (AIDS) in human immunodeficiency virus (HIV), hepatitis, Avian flu, and other viral contagions [3].

Researches dating back to the 1940s have linked a diet deprived in vitamin D with vulnerability to experimental influenza viruses in mice. Influenza epidemics in North America and Europe commonly reach climaxes throughout December during March, the months through which ultraviolet-B (UVB) Radiation exposure and serum levels of $25(\mathrm{OH}) \mathrm{D}$ are lowly in the inhabitants [3].

Shadrin et al., immunized 834 non-immune males (age 16-18 years) with live attenuated influenza virus (B/Dushabbe/66 and B/Leningrad/2/ 67) in St Petersburg $\left(62^{\circ} \mathrm{N}\right)$ and Krasnodar, Russia $\left(\begin{array}{ll}45^{\circ} & \mathrm{N}\end{array}\right)$, during diff erent seasons of the year, contrasting them to 414 vehicle placebo controls. In St Petersburg, they discovered that the attenuated virus was about eight times more probable to induce physical proof of infection (fever) in the winter than the summer $(6.7 \%$ vs.0 .8\%). In Krasnodar, $8 \%$ of immunized persons developed a fever from the virus in January, but only $0.1 \%$ did so in May [4]. 
Zykov and Sosunov discovered that fever after immunization with attenuated H3N2 (221 subjects) was twice as probable in February $(10.7 \%)$ as in June (5\%), contrasted to vehicle placebo controls. They also verified that sero-conversion diverse by season, with the lowest rate of antibody pattern in summer. When they tried to recover the virus $48-72 \mathrm{~h}$ following immunization, they discovered participants were more probable to shed the virus in December $(40 \%)$ than in September $(16 \%)$, and the amount of virus shed was significantly lower in summer than winter, then vitamin $\mathrm{D}$ insufficiency should incline patients to respiratory infections [4].

Influenza, the common cold, respiratory syncytial virus and many other viral infections have climax activities in winter-not merely respiratory system infections but moreover gastroenteritis and diarrhea, meningitis and scarlet fever. The information that internal cancers also have winter time climaxes points to $\mathrm{s}$ that general immune system defenses are concerned. Pandemic influenza shows seasonality parallel to that for epidemic influenza.

The main method whereby vitamin D decreases the jeopardy of bacterial and viral infections attainment the point of clinical symptoms is through generation of the antimicrobial peptide LL-37. Vitamin $\mathrm{D}$, through induction of human cathelicidin, LL-37, reduces the risk of many types of autoimmune disease and several types of cancer. Vitamin D supports the natural immunity to fight bacterial and viral infections to stop them from attainment the phase of clinical symptoms. This theory aids clarify to the seasonality of numerous viral diseases [5].

Vitamin D is occupied in the rule of thousand human genes and has been connected with raises in cardiovascular illness, cancer, autoimmune illness, and infection. Its supplementation shows to mitigate occurrence of these illnesses and may decrease allreason death [6].

\section{Significance of vitamin D supplements with triple therapy to COVID-19}

History of vitamin D insufficiency is a prominent risk factor for minocycline-Induced Cutaneous Hyperpigmentation [7]. Vitamin D and Nacetylcysteine (NAC) both increase glutathione, a strong antioxidant [8]. Study had done by Antonio J. et al showed that; aspirin-resistant patients have elevated plasma levels of three DBP isotypes in comparison to aspirin-sensitive patients, which was related with the malfunction of aspirin to stop both thromboxaneA2 production and platelet activation. Vitamin D binding protein (DBP) prevents the inhibitory influences of aspirin on COX-1 activity, opening a new unexplained method that could be concerned in the aspirin resistant phenomenon [9].

Based on the above mentioned information, I suggest that addition of vitamin D supplements will improve outcomes in COVID-19 patients treated with minocycline, $\mathrm{N}$-acetylcysteine and aspirin triple combined therapy, Invivo and invitro experiments are recommended to test the value of vitamin D supplements added to minocycline - N-acetylcysteine and Aspirin theorized therapy to COVID-19 infection.

\section{REFERENCES}

1. Hansdottir, S., Monick, M. M., Hinde, S. L., Lovan, N., Look, D. C., \& Hunninghake, G. W. (2008). Respiratory epithelial cells convert inactive vitamin D to its active form: potential effects on host defense. The Journal of Immunology, 181(10), 7090-7099.

2. Hansdottir, S., \& Monick, M. M. (2011). Vitamin $\mathrm{D}$ effects on lung immunity and respiratory diseases. In Vitamins \& hormones (Vol. 86, pp. 217-237). Academic Press.

3. Youssef, D. A., Miller, C. W., El-Abbassi, A. M., Cutchins, D. C., Cutchins, C., Grant, W. B., \& Peiris, A. N. (2011). Antimicrobial implications of vitamin D. Dermato-endocrinology, 3(4), 220 229.

4. Cannell, J. J., Vieth, R., Umhau, J. C., Holick, M. F., Grant, W. B., Madronich, S., ... \& Giovannucci, E. (2006). Epidemic influenza and vitamin D. Epidemiology \& Infection, 134(6), 1129-1140.

5. Grant, W. B. (2008). Hypothesis-Ultraviolet- B irradiance and vitamin $\mathrm{D}$ reduce the risk of viral infections and thus their sequelae, including autoimmune diseases and some cancers. Photochemistry and photobiology, 84(2), 356-365.

6. Ginde, A. A., Mansbach, J. M., \& Camargo, C. A. (2009). Vitamin D, respiratory infections, and asthma. Current allergy and asthma reports, 9(1), 81-87.

7. Hanada, Y., Berbari, E. F., \& Steckelberg, J. M. (2016, January). Minocycline-induced cutaneous hyperpigmentation in an orthopedic patient population. In Open forum infectious diseases (Vol. 3, No. 1). Oxford University Press.

8. https://vitamindwiki.com/Vitamin+D+and+Nacety lcysteine+\%28NAC\%29+both+increase+glutathio ne $\% 2 \mathrm{C}+\mathrm{a}+$ great+antioxidant.

9. Lopez-Farre, A. J., Mateos-Caceres, P. J., Sacristan, D., Azcona, L., Bernardo, E., Perez de Prada, T., ... \& Macaya, C. (2007). Relationship between vitamin $\mathrm{D}$ binding protein and aspirin resistance in coronary ischemic patients: a proteomic study. Journal of proteome research, 6(7), 2481-2487. 